\title{
Antioxidant Activity, Antinutritional Factors and Technological Studies on Raw and Germinated Barley Grains (Hordeum vulgare. $\mathrm{L}$ )
}

\author{
Ghazza, Mahfood Ali ${ }^{1}$ and Faten, Farouk Abdelsalam ${ }^{2}$ \\ ${ }^{1}$ Food Science and Technology Dept. Nasser's Faculty of Agricultural Sciences. Aden University. \\ ${ }^{2}$ Food Science and Technology Dept., Fac. of Agric., El-Shatby, 21545, Alexandria Univ., Alexandria, Egypt
}

\begin{abstract}
This study was revealed for investigate the effect of germination on physical, chemical, mineral composition, vitamins content and nutritional characteristics of each variety of Egyptian barley grains (Hordeum vulgare L.) Giza128 (hull- less barley), and Giza134 (hulled barley) were obtained from Agricultural Research Center, Giza. Egypt. Raw barley grains were soaked in water for (12hr.), then germinated for $24,48,72 \mathrm{hr}$. In addition, sensory evaluation was carried out for Talbina prepared from raw barley and germinated (72hr.) barley flours for both varieties (Giza 128, Giza 134) was evaluated.

The results showed that the mean weight and volume of the thousand grains were $50.73 \pm 0.19(\mathrm{~g})$ and $85 \pm 5(\mathrm{ml})$. Also, the density was $0.60 \pm 0.02(\mathrm{~g} / \mathrm{ml})$ for Giza 128 , while the mean weight and volume and density for Giza 134 were $52.72 \pm 1.78(\mathrm{~g}), 85 \pm 5(\mathrm{ml}), 0.62 \pm 0.02(\mathrm{~g} / \mathrm{ml})$, respectively. Moreover, the highest moisture content for both Giza 128 and Giza 134 was noticed during the germination period for $72 \mathrm{hr}$. (11.6\% and $12.4 \%$ ), respectively. Also, the crude protein content was decreased significantly due to soaking treatment, and there were no significant differences for the three germinated treatments compared to the raw sample for Giza128 variety. On the other hand, there were a significant differences between the germinated samples compared with raw and soaked samples. The ash content for soaked barley (12hr.) was decreased for the three germinated samples compared to the raw sample for both varieties. Also, there were significant differences between the five treatments for the mineral composition, there was a decrease in the content of the calcium, magnesium, iron, zinc and manganese in the germinated grains for $72 \mathrm{hr}$. compared with raw grains for both varieties under study. Moreover, there was an increase in vitamin (A, D, Niacin and C) for both Giza 128,134 varieties in germinated grains $(72 \mathrm{hr}$.) compared with the raw grains. Also, Giza 128 variety exhibited higher content of the minerals and vitamins in the raw and the germinated grains (72hr.) compared with Giza 134 variety. On the other hand, the nutritional compounds (total phenol, flavonoids, antioxidant activity (DPPH) and the antinutritional factors (phytic acid, tannic acid and oxalic acid) were decrease in the germinated barley. The decrease in the total phenols, flavonoids antantioxidants activity (DPPH) content in Giza 128 variety was more pronounced $(20.3 \%, 44.4 \%, 12.8 \%)$ than that the in Giza 134 variety $(7.5 \%, 11.1 \%, 9.8 \%)$, respectively.

Also, sensory evaluation for Talbina prepared from raw and germinated (72hr.) barley flours for Giza 128 and 134 varieties was studied. The data revealed that, there were significant differences in case of the color, taste and the overall acceptability between the Talbina prepared from the raw barley flour for Giza 128 and Giza 134 variety, although there were no significant differences in case of the texture and odor for both varieties.
\end{abstract}

Key words: Barley, Germination, Chemical Composition, Minerals, Vitamins, Antinutritional Factors, Talbina.

\section{INTRODUCTION}

Cereal grains constitute a major source of energy and nutrients in the world. The benefits of cereals to human health are the subject of extensive research and epidemiological studies, which have linked whole grain intake to the prevention of metabolic syndrome, obesity, and associated chronic diseases such as cardiovascular disease and two types of diabetes. The health benefits of cereals are primarily caused by their phytochemicals including phenolic acids, flavonoids, vitamins, fiber, and minerals, which act together to combat oxidative stress, inflammation, hyperglycaemia, and carcinogenesis (Poutanen, 2012; Wang, Wu, \&Shyu, 2013).

Barley (Hordeum vulgare L.) is an ancient cereal which has been traditionally used for animal feeding and as raw material in malting industry
(Madakemohekar. et al., 2018). Today, barley remains an important grain in some cultures of Asia and Northern Africa, and in recent years, there has been an increasing interest in using barley as an ingredient in food products due to its nutritional value and high content of biologically active compounds (Martínez, et al., 2018). Most barley varieties are hulled, although several hull-less varieties are also cultivated. Hull-less barley, known as 'naked' barley, requires minimal cleaning compared to hulled barley, as no processing is needed to remove the inedible outer hull. (Madakemohekar, et al., 2018). The use of hull-less barley varieties with high levels of $\beta$-glucans is interesting to obtain functional barley flours that can be easily incorporated into foods to meet the authorized health claims of $\beta$-glucan. Barley flours usually have a higher water absorption ability than 
wheat flours for its greater content of soluble fiber, which can positively affect their baking properties (Holtekjølen, et al., 2008). Barley (Hordeum vulgare L.) is the fourth most importantcereal crop worldwide, after wheat, corn and rice, belonging to family Poaceae (Marwat, et al., 2012). Barley is a cereal grain derived from the annual grass Hordeum vulgare. It has many uses; serves as a major animal fodder, as base malt for beer and certain distilled, and as a component of various health foods. It is used in soups and stews, and in barley bread of various cultures. Barley like wheat and rye contains gluten. In a 2017 ranking of cereal crops in the world, barley was fourth in terms of quantity produced around 148.03 million tons (FAOSTAT, 2017).

Germination, a complex process causing physical, chemical and structural changes in grains, has been identified as an inexpensive and effective technology for improving cereal quality. The germination process is characterized by the growth of the embryo of the grain, manifested by the rootlets growth and increase modification of the contents of the endosperm (Guine \& Correia, 2013)

Germinated cereal grains also show higher total phenolic content and antioxidant activity than those of un-germinated rice, wheat and oat. The germination process improves the nutritional quality of cereal. During the process of germination, significant changes in the biochemical, nutritional, and sensory characteristics of cereals occur due to degradation of reserve materials as used for respiration and synthesis of new cell constituents for developing embryo in the seed (Sharma, Saxena, \&Riar, 2016).

Talbina is an Arabic word made of the word laban which means milk, this may also designate in the case of barley grains when they reach the milky stage, so the inside of these grains is white and liquid resembling milk (Abd El-Hassib, 2007).

Among Arabs, Talbinah food has been used to relieve depression. It is prepared by cooking ground roasted barley with milk for a few minutes and then sweetened with honey. (Aly, Hathout, Sahab, 2011). Aisha, the Prophet Mohammed's wife, used to recommend Talbinah based on a recommendation by the Prophet Mohammed, peace be upon him. (AlBukhari, 2002). "Aisha", used to recommend AtTalbinah for the sick and for those who grieved over a dead person. She used to say "I heard Allah's Apostle saying 'At-Talbinah gives rest to the heart of the patient and makes it active and relieves some of his sorrow and grief."' (Al-Bukhari, 2002). Other than the Hadith and the cultural use, there is little scientific evidence regarding the use of Talbinah in reducing symptoms of depression.

The present study was carried out to determine the chemical composition content as well as minerals, vitamins, nutritional and antinutritional factors of two Egyptian barley grains varieties (Giza 128 \& Giza 134) and their germinated forms. Moreover,Talbina which made from both varieties was assessed for their sensory evaluation.

\section{MATERIALS AND METHODS}

\section{Materials:}

Ten kilograms of each varieties of Egyptian barley grains (Hordeum vulgare L.) Giza128 (hullless barley), and Giza134 (hulled barley) were obtained from Agricultural Research Center, Giza (ARE), Egypt in year 2019.

\section{Chemicals:}

Folin-Ciocalteus, phenol reagent,tannic acid, 1diphenyl-2-picrylhdrazylradical (DPPH) and rutin from Sigma-Aldrich Company (St. Louis, Missouri, USA), all GC chemicals from Fisher Scientific Inc. caffeine standard from ADH company was used. All solvents and chemicals used for analysis were of analytical grade.

\section{Methods:}

Technological methods:

Preparation of raw barley:

For the preparation of raw barley flour, barley grains were thoroughly cleaned from broken seeds, dust and other foreign materials, and then milled. The obtained flour was placed in an air-tight plastic container until use, and stored in refrigerator.

\section{Preparation of germinated barley:}

Soaking: Grains which were freed from broken grains, dust and other foreign materials, and then it soaked in water $(1: 5 \mathrm{w} / \mathrm{v})$ for $12 \mathrm{~h}$ at room temperature.

Germination: The presoaked (12 hr.) grains were spread on wet cotton in aluminum baskets at ambient conditions and watered two to three times a day, grains were germinated for $24,48,72 \mathrm{hr}$ at room temperature $23 \pm 2{ }^{\circ} \mathrm{C}$. The germinated grains were rinsed with distilled water then dried at 55- 60 ${ }^{\circ} \mathrm{C}$ for $24 \mathrm{hr}$., milled to obtain grain sprout flour. The flour was packed in an air-tight plastic container until use, and stored in refrigerator. (Juana, et al., 2005).

\section{Preparation of Talbina:}

Talbina was prepared from raw barley flour (Giza 128, Giza 134) and germinated barley flour for 72hr. (Giza 128, Giza 134). Talbina was prepared by adding whole barley flour to water $(1: 10 \mathrm{w} / \mathrm{v})$ according to (Youssef, 2008) and (1:5 w/v), then the mix was heated at $80 \pm 5^{\circ} \mathrm{C}$ for 5 minutes with continuous stirring until reaching a porridge like texture. Talbina is made by adding one table spoon of barley flour to one cup of cold milk, and stir, then cook on a low heat for 10- 15 minutes with continuous stirring. (Scully and Dumville, 1997). 


\section{Physical methods}

One thousand grain weight, 1000 grain volume was determined according to Williams et al., 1983). Grain weight was calculated as the mean weight of 1000 undamaged barley grains. For the determination of grain volume, grains were transferred to a $250 \mathrm{ml}$ measuring cylinder, and $100 \mathrm{ml}$ distilled water were added. Grain volume was determined as total volume minus 100 . Density $(\mathrm{g} / \mathrm{mL})$ was then determined by dividing the weight of the barley by its volume, using the following formula:

Density $=$ grain weight $/$ grain volume $(\mathrm{g} / \mathrm{ml})$

\section{Chemical methods:}

Moisture, crude protein, crude fat, crude fiber and carbohydrate (by difference) of both raw and germinated barley flour were determined according to the standard A.O.A.C. methods.

Total phenolic (TP) content of barley flour was assayed by Folin -Ciocalteu reagent and tannic acid as a standard (Singleton et al., 1965). The reaction mixture was kept in dark at ambient temperature (22 $\left.{ }^{\circ} \mathrm{C}\right)$ for $(2 \mathrm{hr}$.), before measuring the absorbance at a wavelength of $765 \mathrm{~nm}$ using UV-Vis. Spectrophotometer (Laxco-Alpha-1102, Suite). (Ozgen, et al., 2008).

Total flavonoids content of barley flour were determined spectrophotometrically at a wavelength of $430 \mathrm{~nm}$ using UV-Vis Spectrophotometer (Laxco-Alpha-1102, Suite) as mentioned by (Hmid et al. 2013). The method is based on the formation of a complex of flavonoid- aluminium. Rutin was used as a standard and the flavonoid level was expressed as mg of rutin equivalent per one $\mathrm{kg}$ of sample.

The DPPH (2, 2-diphenyl-1-picrylhydrazyl) radical scavenging activity of methanolic extracts was determined following the method reported by (Jayanthi and Lalitha, 2011) and compared by standard ascorbic acid.

Total tannins content of barley was colorimetrically estimated as tannic acid by subtraction from total polyphenol content as described in AOAC (2000) The total tannins in the extracted polyphenols samples were precipitated by adding polyvenyl pyrroliedone (PVPP), storing at $4^{\circ} \mathrm{C}$ for $15 \mathrm{~min}$ and centrifugation for $10 \mathrm{~min}$ at $3000 \mathrm{rpm}$. Absorbance of the collected supernatant, representing simple phenolic compounds rather than tannins; was measured at a wave length of $760 \mathrm{~nm}$ using UV-Vis Spectrophotometer (Laxco-Alpha1102, Suite). Phytic acid was determined according to (Plaami, 1991) and oxalic acid was estimated followed the guidelines of the AOAC (2000).

\section{Minerals determination:}

Calcium, magnesium, iron, manganese and zinc were determined in flour samples using atomic absorption. The grains were ground, ashed at $450^{\circ} \mathrm{C}$, and digested in $10 \mathrm{~mL} 1 \mathrm{~mol} / \mathrm{L} \mathrm{HCl}$. Minerals $(\mathrm{Ca}$, $\mathrm{Mg}, \mathrm{Fe}, \mathrm{Mn}$ and $\mathrm{Zn}$ ) were measured by atomic absorption spectrometry (AA680, Shimadzu, Japan). Standardized procedures for measuring the mineral element concentrations followed the guidelines of the (AOAC, 2000).

\section{Vitamins determination:}

HPLC technique as described by (Aslam, et al., 2008) and (kozlove, et al., 2003) was used for determination of vitamins (A, D, Niacin, C).

\section{Sensory evaluation:}

Colour, texture, taste, odour and over all acceptability of Talbina were evaluated by randomly chosen ten panelists of the members of the Food Science and Technology Department, Faculty of Agriculture, Alexandria University, Egypt. A ten oint scale was used, whereas; 9 mean the best and 1 means the least, as described by (Piggott, 1988).

\section{Statistical analysis}

All determinations were performed in triplicate $(n=3)$ and the data were expressed as mean \pm standard deviation (SD). Data were statistically analyzed using statistical analysis system ver. 8.1 (2000). A difference was considered statistically significant, when $\mathrm{P}<0.05$, SAS (2004).

\section{RESULTS AND DISCUSSION}

\section{Physical properties of barley grains:}

Some physical properties of barley grains were determined, and the results obtained are presented in Table (1).

The environmental factors, such as rainfall, temperature, soil conditions, fertilization and genetic factors, can contribute to variations in the chemical composition and physical characteristic of cereal grains (Rodehutscord, et al., 2016). The mean weight and volume of the 1000 grains were 50.73 \pm $0.19(\mathrm{~g})$ and $85 \pm 5(\mathrm{ml})$, respectively.

Table 1: Physical properties of barley grains varieties

\begin{tabular}{lcc}
\hline Physical parameters & \multicolumn{2}{c}{ Mean Value* } \\
\cline { 2 - 3 } & Giza 134 & Giza 128 \\
\hline Wt. of 1000 seeds $(\mathrm{g})$ & $52.72 \pm 1.78$ & $50.73 \pm 0.19$ \\
\hline V. of 1000 seeds $(\mathrm{ml})$ & $85 \pm 5$ & $85 \pm 5$ \\
\hline Density $(\mathrm{g} / \mathrm{ml})$ & $0.62 \pm 0.02$ & $0.60 \pm 0.02$ \\
\hline Each value represents the average of three determinations $*$ &
\end{tabular}

Each value represents the average of three determinations.* 
Also, the density was $0.60 \pm 0.02(\mathrm{~g} / \mathrm{ml})$ for Giza 128 , while the mean weight and volume and density for Giza 134 were $52.72 \pm 1.78(\mathrm{~g}), 85 \pm 5(\mathrm{ml}), 0.62$ $\pm 0.02(\mathrm{~g} / \mathrm{ml})$, respectively. Moreover, Farooqui, et al., 2018, showed that the 1000 kernel weight of barley was $42.08(\mathrm{~g})$, density $0.62(\mathrm{~g} / \mathrm{ml})$.

\section{Chemical composition of barley grains:}

Barley differs greatly in chemical characteristics, due to genotype and environment and the interaction between the two. Wide ranges in chemical composition of barley have been reported (Oscarsson, et al., 1996).

The data represented in Table (2) show the chemical composition for the two barley varieties.

Moisture:

It could be seen that the moisture content Table (2) was increased during soaking and germination. The highest moisture content for both Giza 128 and Giza 134 was in the germinated grains for $72 \mathrm{hr}$. (11.6\% and $12.4 \%$, respectively). Moreover, there were no significant differences in the moisture content for Giza 128, whereas there were considerable significant differences for germinated Giza 134. Farooqui et al., 2018, found that the moisture content of non-germinated and germinated barley flour varied between 11.2 to $12.51 \%$ it means that moisture content was increased after germination. Similar to the results were reported by (Khatoon, and Prakash, 2006), in germinated legumes. As germination proceeds, legumes took up water from the surroundings in order for the metabolic process to commence. Dry legumes absorb water rapidly, influenced by the structure of the legume. The increase in water uptake with time is due to the increasing number of cells within the seed becoming hydrated (Nonogaki, et al., 2010).

Fats:

It could be seen from Table (2) that there was a decrease in the fat content for soaked and germinated grains for 24,48 and $72 \mathrm{hr}$. for both varieties (Giza 128 and Giza 134) compared with raw grains. Furthermore, there were considerable significant differences between the five treatments under study for Giza 128, whereas, there was no significant differences between the raw and soaked sample (12 hr.). Although, there were significant differences in the three germinated treatments for Giza 134 variety. Erkan et al., 2006, reported that fat ranged between 1.62-1.92\% in hulled barley and $1.9 \%$ in hull-less barley. Similar results of decrease in the fat content after soaking, germination are reported by Khader, 1983 and Mostafa and Rahma, 1987. Also, Warle et al., 2015, found that the fat content affected by soaking, germination of barley. The fat content decreased from $7 \%$ to $5 \%$ after soaking, germination (96 hr.).

\section{Crude protein:}

Data in Table (2) showed that crude protein content decreased significantly due to soaking treatment, but there were no significant differences for the three germinated treatments compared to the raw sample for Giza128 variety. Also, crude protein content of the soaked sample (12 hr.) was decreased for Giza134 variety, to reach $9.22 \%$ and then it increased during the germination process to reach $14.15 \%$ in the germinated grains for $72 \mathrm{hr}$. Farooqui, et al., 2018, showed that the crude protein increases after germination from $12.69 \%$ to $14.87 \%$, same result also reported by Khader, 1983. Also, Warle, et al., 2015.

found the protein content affected by soaking, germination of barley had an increasing effect on protein content ( $11.25 \%$ to $13.85 \%$ ). Khader, 1983, showed an increase in protein content after germination. The increase in protein content with germination treatment might be due to the reduction in the carbohydrate fractions which utilized during the early stages of germination (Abrahamsen and Sudia, 1966) Likewise, Dagnia, et al., 1992 reported that, the increase in protein could be attributed to the utilization of fats and carbohydrates as energy sources for the developing sprouts. Moreover, Sastryand Tummuru, 1985, reported that the whole kernels protein content was significantly higher in hull-less barley (12.9\%-16.7\%)

Ash:

It could be noticed from Table (2) that the ash content in soaked barley (12hr.) was decreased for the three germinated samples compared to the raw sample for both varieties (Giza 128 and Giza 134). Also, there were significant differences between the five treatments. Ash recorded 2.4-2.8\% in barley from Jordan, morocco and the FAO; (Ereifej and Haddad, 2001). While, Youssef, et al., 2013 showed that it ranged between 2.29-2.86\%. Also, Erkan, et al., 2006, reported that the ash content was higher in hull- less barley $(1.3 \%)$ than hulled barley (0.86$1.03 \%$ ). Moreover, Youssef, et al., 2013 found, that ash content of ungerminated barley flour decreased from $1.59 \%$ to $1.39 \%$ (w.b) during germination. Ash content was significantly decreased in germinated barley, parallel to observations of (Ohtsubo, et al., 2005, Khatoonand Prakash, 2006; and Hahm, et al., 2008). The decrease in ash content represents loss in minerals due to rootlet and washing of the barley in water to reduce the sour smell during the period of germination (Tatsadjieu, et al., 2004).

\section{Crude fibre:}

The data in Table (2) indicated that the crude fiber content for soaked barley as well as for the three germinated samples was increased for both varieties. Also, there was significant difference between the soaked and raw sample for Giza 128 variety, a significant differences was observed between the three and germinated samples compared to the raw sample. 


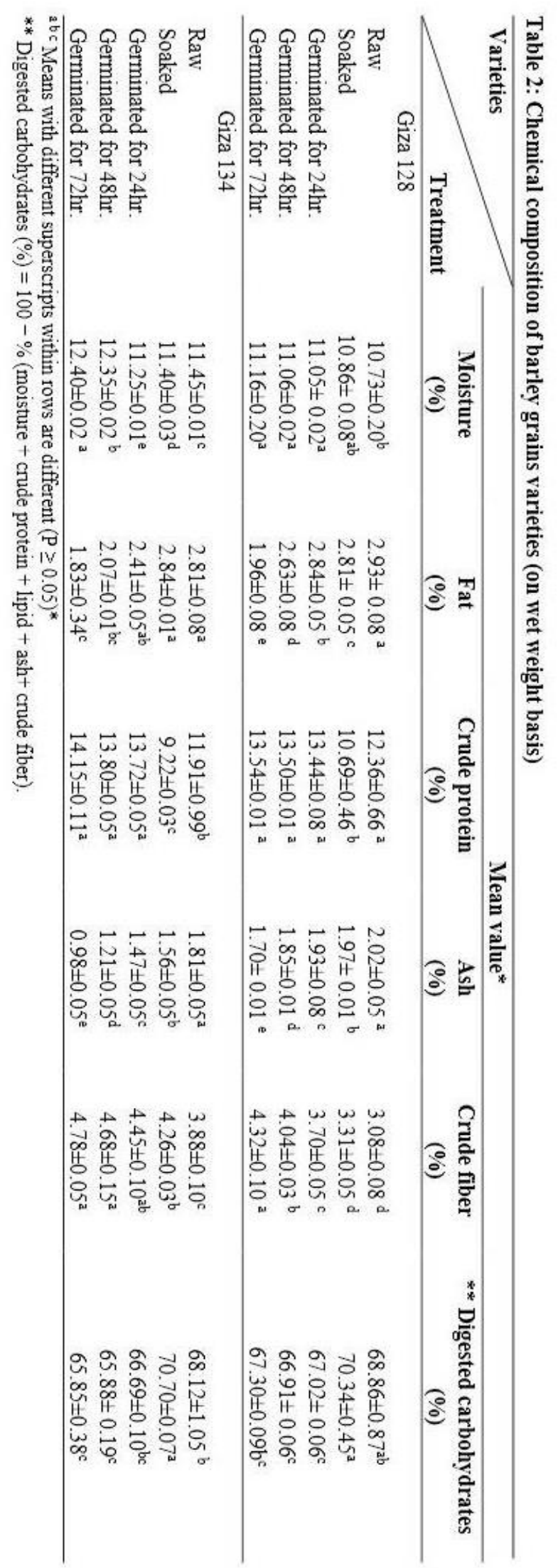


On the other hand, there was no significant differenc between the samples which germinated for 48 and $72 \mathrm{hr}$. Crude fiber recorded 3-4.2\% in barley from Jordan, morocco and the FAO; (Ereifej and Haddad, 2001). While, Youssef, et al., 2013, found that it ranged between $3.83-4.37 \%$. The crude fiber content was higher in the hulled barley $(3.7 \%)$, while it was $1.9 \%$ in the dehulled barley; as well as hull-less barleys had more digestible energy than the hulled cultivars (Wang and Fields 1978). Similar results were shown by Warle, et al., 2015, where they reported that crude fibre was increased in germinated barley from $3.58 \%$ to $5.61 \%$. In germinated rice, the amount of crude fibre was contributed by the presence of bran layer, an outer layer of rice that contained fibre. A study by Azizah, et al., demonstrated that crude fibre was decreased in soaked peanut and mung bean, but conversely increased in soaked rice and soybean. This indicates that germination process affects the level of crude fibre during the period of soaking before the actual phase of germination.

\section{Digested Carbohydrates:}

It could be seen from the results given in Table (2) that there was a significant increase in the digested carbohydrates content during soaking for the two varieties under study. At the same time, the carbohydrates content was decreased after germination compared to the raw sample. Also, there were no differences after germinating for (24 and $48 \mathrm{hr}$.) for Giza 128 variety as well as for Giza 134 variety for (48 and $72 \mathrm{hr}$.), carbohydrates recorded 75.7-87.2\%; in barley from Jordan, morocco and the FAO; (Ereifej and Haddad, 2001). Also, Farooqui, et al., 2018, found that carbohydrates content, in barley before and after germination ranged from 68.9 to 63.79 . Moreover, Chauhan, et al., 2015, showed that there was significant difference in carbohydrate content among amaranth before and after germinated flours. The decrease in carbohydrates in germinated grains may be attributed to increase in alph-amylase activity which breakdown complex carbohydrates into simpler and more absorbable sugars (Hung, et al., 2011). The soaking, germination treatments given to barley grains decreased the total carbohydrate contents $72.02 \%$ to $61.06 \%$ in germinated flour of barley, due to the active respiration process during soaking and germination (Warle, et al., 2015)

\section{Mineral composition of barley grains:}

As shown in Table (3) there was a decrease in the content of the calcium, magnesium, iron, zinc and manganese in the germinated grains for $72 \mathrm{hr}$. compared with raw grains for both varieties under study. Also, Giza 128 variety exhibited higher content of the minerals in the raw and the germinated grains (72hr.) compared with Giza 134 variety. Svetlana, and Ozcan, 2016, reported that mineral content in raw barley as calcium, magnesium, iron, manganese, zinc, 487, 1724, 57.7, $18.8,21.7(\mathrm{mg} / \mathrm{kg})$ respectively. On the other hand, Farooqui et al., 2018, showed that the mineral composition of barley were analyzed and results revealed that macro-elements such as calcium, magnesium increased with germination from 110 to 130,160 to $180(\mathrm{mg} / 100 \mathrm{~g})$, respectively. While the micro elements as iron, manganese were reduced with germination from 8.70 to $7.1,1.54$ to 1.49 respectively. Also, zinc is increases from 2.92 to $3.48(\mathrm{mg} / 100 \mathrm{~g})$. The results reported are in close agreement with these findings of (Hubner, et al., 2010). As compared to un-germinatedseed, germinated seeds contain low mineral content (Narsih, 2012; Sharma, Saxena, \& Riar, 2016).

\section{Vitamin content of barley grains:}

As shown in Table (4), there was an increase in vitamins A, D, C and Niacin for both Giza 128,134 varieties in germinated grains for $72 \mathrm{hr}$. compared with the raw grains. Also, Giza 128 variety exhibited higher content of the vitamins under study in both the raw and the germinated grains ( $72 \mathrm{hr}$.) compared with Giza 134 variety.

Vitamins are important micronutrients required by the human body for normal growth and selfmaintenance. Vitamins are grouped into categories such as fat and water-soluble vitamins and a lack of vitamins may lead to vitamin deficiencies which can cause health problems (Ottaway, 2008; Dionex Corporation, 2010). Warle, et al., 2015 have been reported that germination improves the bioavailability of the various minerals, vitamins and crude fibers along with the nutritional profile of the seed grains

The vitamin A in hulled barley was 22 (IU/ 100g), (National Standard Reference, 2018). Moreover, Lebiedzinska and Szefer, 2006), have reported that a niacin content in barley was 4.07 $\mathrm{mg} / 100 \mathrm{~g}$. Also, niacin in hulled barley was 4.604 $\mathrm{mg} / 100 \mathrm{~g}$ (National Standard Reference, 2018). Niacin increased during germination in both soybean and mung bean, but the highest values for this vitamin were observed in sprouted peas (Burkholder and Veigh, 1994).

Also, Kim, et al., 1993, reported that the nutritional value of soybean sprouts changes during the germination; the vitamin $\mathrm{C}$ content increases approx. to its 200 -fold value compared to the nongerminated seed, at the same time, in the course of two, three, four, five, six and nine days of sprouting the nutritional value of the lupine sprouts increased significantly owing to the increase of the vitamin C content. 


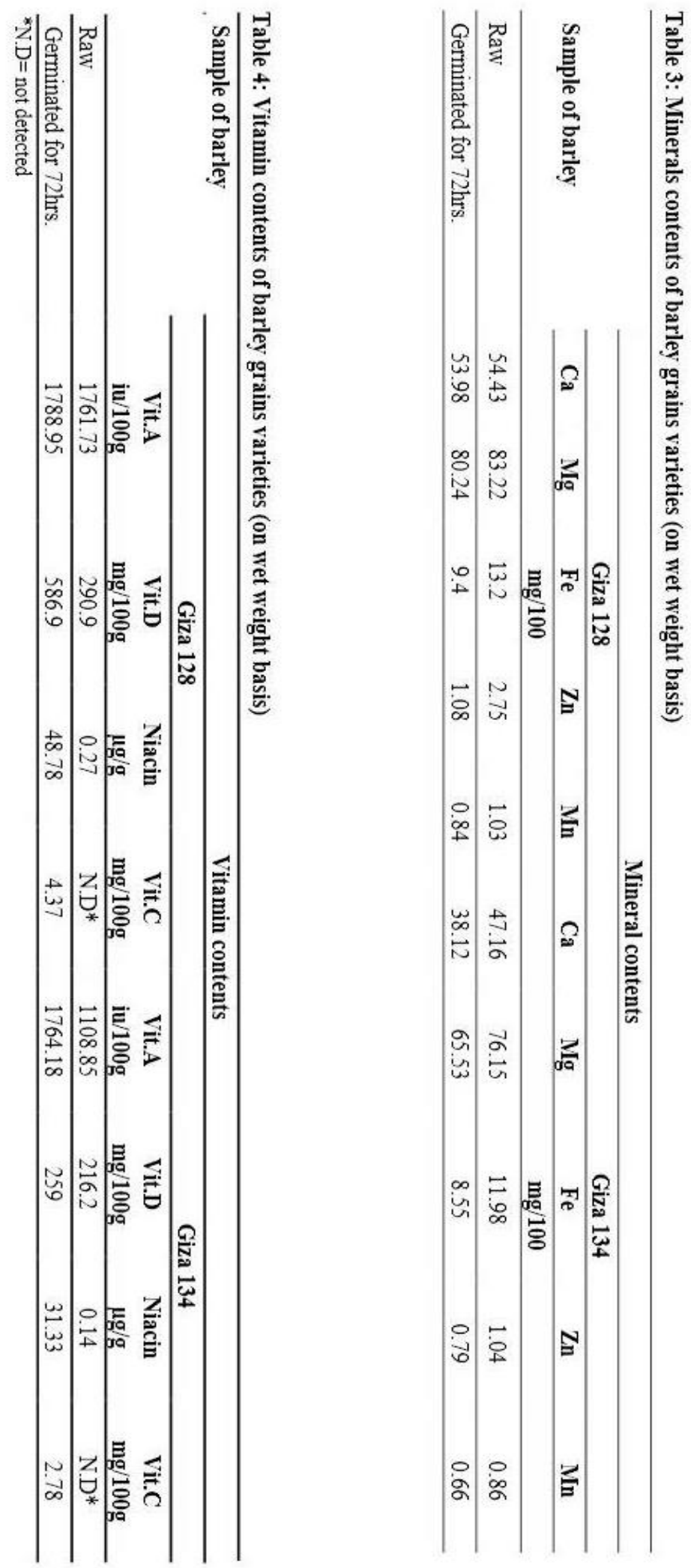




\section{Nutritional and antinutritional content of barley grains:}

Total phenol, flavonoids and antioxidant activity (DPPH):

It could be seen that the results given in Table (5) that the total phenols were decreased in both Giza 128 and 134 varieties (germinated grains for $72 \mathrm{hr}$.) compared with the raw grains. Meanwhile, the decrease in the total phenols content for Giza 128 variety was more pronounced $(20.3 \%)$ than the decrease in Giza 134 variety (7.5\%). On the other hand, the flavonoids content decreased for both varieties Giza 128 and Giza 134 in the germinated sample for $72 \mathrm{hr}$. compared with the raw sample. Although, the decrease in the flavonoids content was more pronounced in Giza 128 variety (44.4\%) compared with the decrease in Giza 134 variety $(11.1 \%)$. The data presented in Table (5) reveals that there was a significant decrease in the DPPH content $(12.8 \%)$ in germinated grains for $72 \mathrm{hr}$. for Giza 128 variety, and $9.8 \%$ only for Giza 134 variety (germinated for $72 \mathrm{hr}$.) compared with the raw grains. Pokorn, 2007, reported that the antioxidants have become one of the most important concerns in human nutrition because of high concentration of free radicals, both in food and after food ingestion. Moreover, Farooqui, et al., 2018, showed that the nutritional composition such as total phenolic content, antioxidant activity and total flavonoids content of barley flour before and after germination were ranged from 2.12 to 1.85 (mg ferulic acid equivalents/g), 11.37 to $14.36 \%$ and 0.29 to 0.37 (mg catechin equivalents/g). Thease results are in close agreement with these findings of (Lu et al. 2007). Warle, et al., 2015, reported that the germination not only improves the bioavailability of the various minerals, vitamins and dietary fibers along with the nutritional profile of the seed grains, but also reduces some antinutritional factors. Polyphenols are the biggest group of phytochemicals that have been found in plant-based foods and have been linked to several health benefits. Therefore, dietary polyphenols have received tremendous attention among nutritionists, food scientists, and consumers due to their roles in human health (Tsao, 2010). On the other hand, Yang, et al., 2013 analyzed the profiles of common flavonoids in unhulled purple barley, normal barley, and hulled purple barley. The bran-rich fraction of barley grain contained the most flavonoid content, whereas the hull fraction did not contain any significant flavonoid content. The total average content of flavonoids in hulled purple barley (124.8 $\mathrm{mg} / \mathrm{g}$ ) was significantly higher than that in unhulled purple barley $(69.40 \mathrm{mg} / \mathrm{g})$ and normal barley $(48.50 \mathrm{mg} / \mathrm{g})$. Durazzo, et al., 2014, found that total flavonoid content varies within the range $114-227$ $\mathrm{mg} / 100 \mathrm{~g}$ for Italian barley. However, for twenty Japanese barley landraces, total flavonoid content varied from 154 to $324 \mathrm{mg} 100 \mathrm{~g}$. Several factors affect the phenolic content and availability, including environmental conditions, agronomic practice (Gelinas, and Kinnon, 2006) and industrial or domestic processing (Ózer, et al.,2006). Moreover, Kim, et al., 2007, studied the flavonoid content of 127 lines of hulled and unhulled colored barley wherein the total flavonoid content was found to range between 62.0 and $300.8 \mathrm{mg} / \mathrm{g}$. Arif, et al., 2011, reported that germination of grains including wheat and barley results in increased concentration of some phytochemicals such as phenolic compounds, flavonoids, and tannins. After germination, the percent relative nutritive value of wheat and barley increases. Clinical studies indicate that flavonoids may be the bioactive substances present in cereal grains responsible for the moderation of many diseases including cancer and coronary heart diseases (Gani, et al., 2012). Generally, the content of flavonoids in barley grains are proportional to the degree of color depth, and blue and purple barley grains have been discovered to possess the most flavonoid content among barley varieties (Liu, 2013).

Table 5: Nutritional and antinutritional content of the barley grains varieties (on wet weight basis)

\begin{tabular}{lcccc}
\hline & \multicolumn{2}{c}{ Giza 128 } & \multicolumn{2}{c}{ Giza 134 } \\
\cline { 2 - 5 } Nutrient/anti-nutrient compound & Raw & $\begin{array}{c}\text { Germinated } \\
\text { for 72hr. }\end{array}$ & Raw & $\begin{array}{c}\text { Germinated } \\
\text { for 72hr. }\end{array}$ \\
\hline Total phenol (mg/kg) & $76.59 \pm 0.29^{\mathrm{a}}$ & $61.13 \pm 0.62^{\mathrm{b}}$ & $59.64 \pm 0.43^{\mathrm{a}}$ & $55.17 \pm 0.24^{\mathrm{b}}$ \\
Flavonoids (mg/kg) & $75.20 \pm 0.01^{\mathrm{a}}$ & $41.83 \pm 0.88^{\mathrm{b}}$ & $37.44 \pm 0.17^{\mathrm{a}}$ & $33.29 \pm 0.25^{\mathrm{b}}$ \\
DPPH radical scavenging activity $(\%)$ & $38.22 \pm 0.09^{\mathrm{a}}$ & $33.33 \pm 0.07^{\mathrm{b}}$ & $35.54 \pm 0.04^{\mathrm{a}}$ & $32.06 \pm 0.13^{\mathrm{b}}$ \\
Phytic acid (mg/g) & $0.90 \pm 0.02^{\mathrm{a}}$ & $0.63 \pm 0.02^{\mathrm{b}}$ & $0.88 \pm 0.04^{\mathrm{a}}$ & $0.56 \pm 0.01^{\mathrm{b}}$ \\
Oxalic acid (mg/g) & $6.04 \pm 0.09^{\mathrm{a}}$ & $3.27 \pm 0.17^{\mathrm{b}}$ & $5.55 \pm 0.20^{\mathrm{a}}$ & $2.93 \pm 0.48^{\mathrm{b}}$ \\
Tannic acid (mg/g) & $21.10 \pm 0.54^{\mathrm{a}}$ & $17.70 \pm 0.41^{\mathrm{b}}$ & $18.40 \pm 0.17^{\mathrm{a}}$ & $11.26 \pm 0.28^{\mathrm{b}}$ \\
\hline
\end{tabular}

$\mathrm{a} \mathrm{bc}$ Means with different superscripts within rows are different $(\mathrm{P} \geq 0.05$ 


\section{Phytic acid, oxalic acid and tannic acid:}

The data represented Table (5) indicated, antinutritional factor in raw and germinated barley. There was a significant decrease in the phytic acid content for both varieties Giza 128 and Giza 134 (30\% and $36 \%$, respectively) during the germination for $72 \mathrm{hr}$. compared with the raw sample. Moreover, there was a significant decrease in the oxalic acid content in germinated grains for $72 \mathrm{hr}$. in both varieties Giza 128 (45.9\%) and Giza 134 (47.2\%). Furthermore, there was a significant decrease in the tannic acid content in the germinated grains for 72 hr. in both varieties Giza 128 (16.1\%) and Giza 134 (18.8\%). Gupta and Sehgal 1991, observed a decrease in phytic acid contents of cereal grains used for preparing weaning foods as a result of soaking and germination. The decrease in the level of phytic acid during soaking may be attributed to leaching the acid out into soaking water under the concentration gradient (Abd El Rahaman et al., 2007; Vadivel, et al., 2011). Other researchers have reported a decrease in the level of phytic acid during germination due to phytase activity in the germinating grains). Phytase activity was observed during germination of wheat, barley, rye and oats, which hydrolyze phytate to phosphate and myoinositol phosphates (Larsson and Sandberg, 1992). Germination of pearl millet grains at $30^{\circ} \mathrm{C}$ for $24 \mathrm{hr}$. reduced the phytic acid by more than $50 \%$ (Khetarpaul and Chauhan, 1990). Sokrab, et al., 2012, reported that phytic acid content of both genotypes decreased significantly within the first 2 days of germination There after, it decreased at a lower rate from day 4 to 6 day of germination and the reduction exceeded $80 \%$ at the end of germination process for both genotypes. The results showed that germination had significantly reduced phytic acid content of the genotypes grains with time. Warle, et al., 2015 reported that the germination not only improves the bioavailability of the various minerals, vitamins and dietary fibers along with the nutritional profile of the seed grains, but also reduces some anti- nutritional factors. Barley (Hordium vulgare) is classified as a low oxalate plant and, like many other crops, produce sand accumulates oxalic acid, but its biosynthesis, accumulation, and catabolism are not yet sufficiently known (Wagner, 1981). Caliskan, 2000, reported that oxalic acid and its salts are produced and stored in different amounts in all part of plant, but that their levels may vary depending on the age of the plants, the growing season and cultivation condations. Formation of oxalic acid may occur by several pathways. Brudzynski, and Salamon, 2011, reported that most of investigated barley samples showed an oxalic acid content between 39.5 and $65.3 \mathrm{mg} / \mathrm{kg}$ (d.m.) compared to data cited by (Wagner, 1981). Important grains which are used for human and animal consumption are known to contain a significant amount of tannin contents like sorghum (Sorghum bicolor), millet (Panicum milisceum), barley (Hordeum vulgare) and anumber of other legume seeds (Kumar, 2007). Tannins are phenolic plant secondary compounds, with ranging molecular weights and complexity (Waghorn, 2000). Also, Makkar, 2003 reported that widely distributed in nature and are the fourth most abundant plant constituent following cellulose, hemicellulose and lignine. Tannins have several specific properties: antibacterial, antitumor, antivirus and antimutagenic functions. Plant tannins have also beneficial properties to human health (Kumari, 2012). The condensed tannin content of the complementary food ranged from 1.12 to 2.71 $\mathrm{mg}$ catechine quivalent/100 g. The observed reduction in tannin content after germination was a result of formation of hydrophobic association of tannins with seed proteins and enzymes. In addition, loss of tannins during germination may also be due to the leaching of tannins into the water (Shimelis and Rakshit, 2007) as well as washing during germination and binding of polyphenols with other organic substance such as carbohydrate or protein. (Khetarpaul, and Bishnoi, 2002).

\section{Sensory evaluation of Talbina of barley grains varieties:}

Table (6) showed the sensory evaluation results for Talbina prepared from raw and germinated (72hr.) barley flour for Giza 128 and 134 varieties which conclude the color, texture, taste, odor as well as the overall acceptability.

1- There was a significant decrease in the five characteristics (color, texture, taste, odor and overall acceptability) for the germinated barley (72hr.) compared to the raw barley for Giza 128 variety.

2- There were no significant differences for the color, texture, odor and overall acceptability between the raw and germinated barley (72hr.) sample for Giza 134 variety, although there was significant differences between the two samples in case of taste.

3- There were significant differences in all the organoleptic characteristics under study between the Talbina prepared from the raw barley flour for Giza 128 and Giza 134. The results of Giza 128 variety were higher compared to Giza 134 variety.

4- Also, there were significant differences in case of the color, taste and the overall acceptability between the Talbina prepared from germinated for (72hr.), barley flour for Giza 128 and Giza 134 variety, although there were no significant differences in case of the texture and odor for both varieties. 


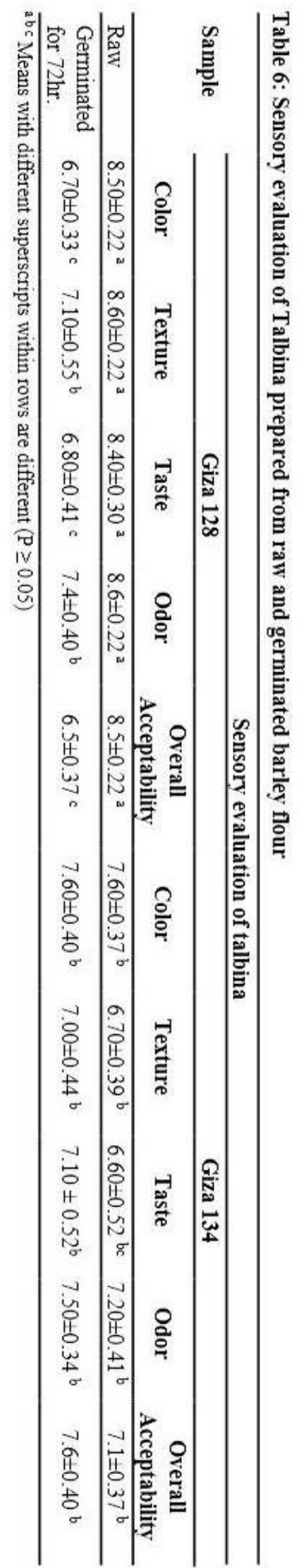


Talbina is a popular traditional food product in the Arab world prepared by mixing barley flour and milk and cooking for 10 to 15 minutes. In Islam, Talbina was prescribed for seven diseases (Hadith), these include grief, high cholesterol levels, heart disease, treatment of cancer, effects of aging, diabetes and hypertension.

Talbina is a food product with high potential applications as a functional food. (Youssef, et al., 2013)

Nowadays, the main changes in demand for agricultural and food products are being fueled by population growth and lifestyle modifications. Many food manufacturers today are looking to replace wheat flour by alternative flours to be included in new formulations with high nutritive value and bioactive properties. (Vicentini, et al., 2016).

\section{CONCLUSION}

In the present study germination of barley was carried out under controlled conditions of soaking, germination. From the result, it can conclud that chemical, mineral and nutritional properties were significantly influenced by the germination process. A significant decrease in crude fat, ash and carbohydrate of the two varieties of barley, (Giza 128 and Giza 134). Moreover, the minerals content, as $\mathrm{Ca}, \mathrm{Mg}, \mathrm{e}, \mathrm{Zn}$ and $\mathrm{Mn}$, decreased by the germination process for (72 hr.). Furthermore, vitamins content (A, D, Niacin and $\mathrm{C}$ indicated shown to increase in germinated flour (72 hr.) for both Giza 128, and Giza 134 varieties, Also, nutritional properties as total polyphenols, flavonoids and antioxidant activity were decreased in the germinated flour. On the other hand, it was found that germination process improved the sensory evaluation of Talbina product compared with that prepared from raw one.

\section{REFERENCES}

Abdel-Hassib, R., (2007). Telbina: A food and drug. Mecca, K.S. International organization of the holey quran and hadith.

Abrahamsen, M., and Sudia, T.W. (1966) Studies on the soluble carbohydrate and carbohydrate precursors in germinating soybeans. Amer $\mathbf{J}$ Bot. 53: 108-114.

Al-BukhariMI. (2002). [Food.Hadith 5417]. In Sahih Al-Bukhari. 1st ed. Damascus: Dar IbnKather;:1 379. Arabic.

Aly, S.E., Hathout, A.S., Sahab, A.F. (2011) Application of Hazard Analysis Critical Control Points in Dairy Products: A Case Study of Probiotic Talbina. Nature and Science.; 9(7): 102-113.

A.O.A.C. (2000). Association of Official Analytical Chemists, Official Methods of Analysis. 17 th Ed. Washington.
Arif, M., Bangash, J.A., Khan, F., Abid, H. (2011). Effect of soaking and malting on the selected nutrient profile of barley.Pakistan J. Biochem. Mol. Biol. 44, 18-21.

Aslam, J., Mohajir, A.S., Khan, S.A., Khan, A.Q. (2008). HPLC analysis of water soluble vitamins (B1, B2, B3, B5, B6) in In Vitro and ex vitro germinated chickpea (Cicer arietinum L.). African Journel of Biotechnology vol 7: (14), pp.2310- 2314,18 july, 20008.

Azizah, A. H., and Zainon, H. (1997). Effect of processing on dietary fibre contents of selected legumes and cereals. Malaysia Journal of Nutrition 3(2): 131-136,

Burkholder, and Veigh, (1994). The increase of B vitamins in germinating seeds.Proc Nat. Acad. Sci. 28: 440-446.

Caliskan, M. (2000). The metabolism of oxalic acid.Turk.J. Zool.24, 103-106.

Chauhan,A., Saxena, D.C., Sukhcharn, S. (2015). Total dietary fibre and antioxidant activity of gluten free cookies made from raw and germinated amaranth (Amaranthus spp.).LWTFood Science and Technology.63: (2) 939-945.

Dagnia, S.G., Petterson, D.S., Bell, R.R., and Flanagan, F.V. (1992). Germination alters the chemical composition and protein quality of lupin seeds. J Sci Food Agric 60: 419-423.

Dionex Corporation. (2010). Determination of water- and fat-soluble vitamins by HPLC (Technical Note, No. 89, LPN 2598). Sunnyvale:Dionex Corporation. Retrieved from https://tools.thermofisher.com/ content/sfs/brochures/88784-TN89-HPLCWaterFatSolubleVitamins- 27Oct

Durazzo, A.,Valeria Turfani, V., Azzini, E. Maiani, G., Carcea, M.(2014) "Antioxidant Properties of Experimental Wholegrain Pastas Made With Different Cereals". Journal of Food Research.Vol.3(4).

Ereifej, K.I. and Haddad, S.G. (2001) Chemical composition of selected jordanian cereals and legumes as compared with the FAO, Moroccan, East Asian and Latin American tables for use in the Middle East. Trends in Food Sci and Technol 11: 374-378.

Erkan, H., Çelik, S., Bilgi, B., and KÖksel, H., (2006). A new approach for the utilization of barley in food products: Barley tarhana. Food Chem. 97: 12-18.

FAOSTAT. (2017). Food and Agriculture Organization of the United Nations.

Farooqui, A.S, Syed, H.M.Talpade N.N.,Sontakke, M.D., and Ghatge, P.U. (2018) Influence of germination on chemical and nutritional properties of Barley flour. Journal of Pharmacognosy and Phytochemistry; 7(2): 3855-3858. 
Gani, A., Wani, S., Masoodi, F., Hameed, G. (2012). Whole-grain cereal bioactive compounds and their health benefits: a review. J Food Process Technol.

Gelinas, P, and McKinnon.C. (2006)." Effect of wheat variety, farming site, and bread-baking on total phenolics". International Journal Food Science and Technology, Vol. 41, p: 329-332.

Guine, D.F. Correia, D. P.M. (2013). Engineering Aspects of Cereal and Cereal Based Products: CRC Press, 53-55.

Hahm,T., Park, S., and Lo, Y. M.(2008). Effects of germination on chemical composition and functional properties of sesame (Sesamum indicum L.) seeds.Bioresource Technology $\mathbf{1 0 0}$ (4), 1643-1647.

Hmid, I., Elothmani, D., H., Oukabli, A, and Mehinagic, E. (2013). Comparative study of phenoli compounds and their antioxidant attributes of eighteen pomegranate (Punica granatum L.) cultivars grown in Morocco. Arabian Journal of Chemistry.

Holtekjølen, A.K.; Olsen, H.R.; Færgestad, E.M.; Uhlen, A.K.; Knutsen, S.H. (2008). Variations in water absorption capacity and baking performance of barley varieties with different polysaccharide content and composition. LWT Food Sci. Technol. 2008, 41, 2085-2091.

Hubner, F., Neil, T.O, Cashman, K.D. (2010).The influence of germination conditions on betaglucan, dietary fiber and phytate during the germination of oats and barley. Eur. Food Res. Technol.; 231: 27-35.

Hung PV, Tomoko M, Syota Y, Naofumi M. (2011). Effects of germination on nutritional composition of waxy wheat. J Sci. Food Agric.; 92: 667-672.

Jayanthi, P. and Lalitha, P. (2011). Reducing power of the solvent extracts of Eichhorniacrassipes (MART) solms. International Journal of Pharmacy and Pharmaceutical Sciences. 3: 126128.

Juana, F., Martha, L., Miranda R.D., Concepcion, V.V. (2005). Effect of germination and Fermentation on the anti-oxidant vitamin content and antioxidant capacity of (Lupines albus L.) var. Multolupa. Food Chemistry; 92: 211-220.

Khader, V. (1983). Nutritional studies on fermented, germinated and baked soyabean (Glycine max) preparations. J plant foods. 5: 31-37.

Khatoon, N, Prakash J. (2006). Nutrient retention in microwave cooked germinated legumes. Food Chemistry; 97(1):115-121.

Khetarpaul, N., \&Bishnoi, S. (2002). Antinutrients and protein digestibility of Faba bean and Rice bean as affected by soaking, dehulling and germination. Journal of Food Science \&Technology, 39, 418-422.
Kim, M.J. Hyun, J.N., Kim, J.A, Park, J.C., Kim, M.Y., Kim, J.G., Lee, S. J., Chun, S.C., Chung, I.M. (2007). Relationship between phenolic compounds, anthocyanins content and antioxidant activity in colored barley germplasm. J Agric Food Chem.; 55: 4802e9.

Kim,S.D.,Kim, S.H. Ki, Hong, E.H. (1993). Composition of soybean sprout and its nutritional value, Korean Soybean Sigest, 10, 19.

Kozlov, E.I., Solunina, I.A., Lyubareva, M.L., Nadtochii, M.A.(2003) HPLC determination of vitamins $\mathrm{A}, \mathrm{D}$, and $\mathrm{E}$ in multivitamins composition pharmoceutical chemistry journelvol: 37, No10 pp. 50-53. October.

Kumar, V., Elangovan, A.V., Mandal, A.B.Tyagi, Bhanja, S.K, Dash. B.B. (2007)."Effects of feeding raw or reconstituted high tannin red sorghum on nutrient utilization and certain welfare parameters of broiler chickens". Brit. Poult. Sci., Vol. 14, p: 198-204

Kumari, M. and Jain, S. (2012)."Tannins: An Antinutrient with Positive Effect to Manage Diabetes". Research Journal of Recent Sciences, vol. 1(12), p: 70-73.

Larsson, M., Sandberg, A.S. (1992). Phytate reduction in oats during malting. J. Food Sci. 57, 994-997.

Lebiedzinska and Szefer (2006). vitamins B in grain, cereal-grain, food soy- products and seeds. Food Chem 95(1): 116-122

Liu, Z., Liu, Y. Pu, Z., Wang, J., Zheng, Y, Li, Y. Wei, Y. (2013). Regulation, evolution, and functionality of flavonoids in cereal crops. BiotechnolLett.; 35: 1765e80.

Lu, J., Zhao, H.F., Chen, J., Fan, W., Dong, J.J., Kong, W.B. (2007). Evolution of phenolic compounds and antioxidant activity duringmalting. Journal Agricultural Food Chemistry.; 55:10994-1100

Madakemohekar, A.; Prasad, L.C.; Pal, J.P.; Prasad, R. (2018). Estimation of combining ability and heterosis for yield contributing traits in exotic and indigenous crosses of barley (Hordeum vulgare L.). Res. Crop., 19, 264-270.

Madakemohekar, A.; Prasad, L.C.; Prasad, R. (2018). Generation mean analysis in barley (Hordeum vulgare L.) under drought stress condition. Plant Arch., 18, 917-922.

Makkar, H.P.S. (2003). "Effects of fate of tannins in ruminant animals,adaptation to tannins and strategies to overcome detrimental effects of feeding tannin-rich feeds". Small Ruminant Research, Vol. 49, p: 241-256. 
Martínez, M.; Motilva, M.J.; de lasHazas, M.C.L.; Romero, M.P.; Vaculova, K.; Ludwig, I.A. (2018). Phytochemical composition and $\beta$-glucan content of barley genotypes from two different geographic origins for human health food production. Food Chem., 245, 6170 .

Marwat, S. K., Hashimi, M., Khan K. U., Khan, M. A., Shoaib, M., Fazal-ur-Rehman. (2012). Barley (Hordeumvulgare L) AProphetic Food Mentioned in Ahadith and its Ethnobotanical Importance. American-Eurasian Journal of Agricultural and Environmental Sciences.12 (7).

Mostafa, M. M., Rahma, E. H., and Reddy, A. H. (1987). Chemical and nutritional changes in soyabean during germination. Food Chem 23(4): 257-275.

Narsih, H.Y. (2012). The study of germination and soaking time to improve nutritional quality of sorghum seed. International Food Research Journal, 19(4), 1429-1432.

National Nutrient Database for Standard Reference 1 Release April, 2018.

Nonogaki, H., Bassel, G.W. and Bewley, J.W. (2010). Germination-still a mystery. Plant Science doi:10.1016/j.plantsci.

Ohtsubo, K., Suzuki, K., Yasui, Y., and Kasumi, T. (2005). Bio-functional components in the processed pregerminated brown rice by a twinscrew extruder. Journal of Food Composition and Analysis 18 (4), 303-316.

Oscarsson, M. (1996). "Chemical composition of barley samples focusing on dietary fiber components". Journal of Cereal Science.16: 1170.

Ottaway, P. B. (2008). Food fortification and supplementation.Technological, safety and regulatory aspects .England: CRC Press.http://dx.doi. org/10.1533/9781845694265.

Ózer, E.A., Herken, E.N., Guzel, S. Ainsworth, P. Ibanoglu,, S. (2006)."Effect of extrusion process on the antioxidant activity and total phenolics in a nutritious snack food. International Journal of Food Science and Technology, Vol. 4, p: 289-293.

Ozgen.M.; Durgac, C.; Scree, S. \& Kaya, C., (2008). Chemical and antioxidant properties of pomegranate cultivars grown in the Mediterranean region of Turkey. Food Chemistry, 111:703-706.

Piggott,I.R. 1988. Sensory Analysis of Foods.2 nd edition. Elsevier Applied Science, London, New York.

Plaami, S., and Kumpulainen,J. (1991) Determination of phytic acid in cerials using ICP AOAC.74: 32-6.
Pokorn, Y. J. (2007). Are natural antioxidants better and safer than syntheticantioxidants? Eur. J. Lipid Sci. Technol., 109 (6), 629-642

Poutanen, K. (2012). Past and future of cereal grains as food for health. Trends in Food Science and Technology, 25(2), 58-62. DOI: 10.1016/j.tifs.02.003.

Rodehutscord M., Ruckert C., Maurer H. P., Schenkel H., W., Knudsen K. E. B., Schollenberger M., Laux M., Eklund M., Siegert W., Mosenthin R. (2016). Variation in chemical composition and physical characteristics of cereal grains from different genotypes.Archives of Animal Nutrition.70 (2). P. 87-107.

SastryCSP and Tummuru MK. (1985) spectrophotometric determination of tryptophan in proteins. J Food SciTechnol 22: 146-147

Scully, Terence; Dumville, DN. (1997). The art of cookery in the Middle Ages. Boydell Press. pp. 187-88. ISBN 0-85115-430-1.

Sharma, S., Saxena, D.C., Riar, C.S. (2016). Analysing the effect of germination on phenolics, dietary fibres, minerals and $\gamma$-amino butyric acid contents of barnyard millet (Echinochloafrumentaceae).Food Bioscience. 13(1):60-68. DOI: 10.1016/j.fbio..12.007.

Shimelis, E. A., \&Rakshit, S. K. (2007). Effect of processing on antinutrients and in vitro protein digestibility of kidney bean (Phaseolus vulgaris L.) varieties grown in East Africa. Food Chemistry, 103, 161-172. doi:10.1016/j.foodchem.2006.08.005

Singleton,V.L., Joseph,A. and Rossi,J.R. (1965). Colorometry of total phenolics with phosphomolybdic- phosphotungstic acid reagents. American Journal of Enology and Vticulture.16: 144-153.

Sokrab, A. M., Ahmed, I.A., Babiker E.E. (2012). Effect of germination on antinutritional factors, total, and extractable minerals of high and low phytate corn (Zea mays L.) genotypes. Journal of the Saudi Society of Agricultural Sciences. 11, 123-128.

Svetlana, N and Ozcan, M.M, (2016). Mineral contens of malted barley grains used as the raw material of beer consumed as traditional spirits. Indian Journal of Traditional Knowledge. vol.15: (3), July, pp.500-502.

Tatsadjieu, N. L., Etoa, F. X., and Mbofung, C. M. F. (2004). Drying Kinetics, physicochemical and Nutritional Characteristics of "Kindimu", a Fermented Milk- Based-Sorghum-Flour. The Journal of Food Technology in Africa 9(1):1722.

Taso, R. (2010). Chemistry and Biochemistry of dietary polyphenols. Nutrients 2(12):12311246. 
Vadivel, V., Stuetz, W., Scherbaum, V., Biesalski, H.K. (2011). Total free phenolic content and health relevant functionality of Indian wild legume grains: effect of indigenous processing methods. J. Food Comp. Anal. 24, 935-943.

Vicentini, A.; Liberatore, L.; Mastrocola, D. (2016). Functional foods: Trends and development of the global market. Ital. J. Food. Sci, 28, 338351.

Waghorn, G.C, Shelton, I.D, McNabb, W.C. (2000) ). "Effects of condensed in Lotus peunculatus on its nutritive value for sheep. 1. Non nitrogenous aspects". J. Agric. Sci. Vol.123, p: 99-107.

Wagner, G.J. (1981). Vacuolar deposition of ascorbate-derived oxalic acid in barley. Plant Physiol.67, 591-593.

Wang, Y.Y.D., and Fields (1978) Germination of corn and sorghum in the home to improve nutritive value. J Food Sci 43:1113-1115.
Wang, C. Y., Wu, S.-J., \&Shyu, Y.-T.(2013). Antioxidant properties of certain cereals as affected by foodgrade bacteria fermentation. Journal of Bioscience and Bioengineering, 117(4), 449-456. DOI: 10.1016/j..10.002.

Warle, B. M., RiarC. S., Gaikwad S.S. and Mane V. A. (2015). Effect of germination on nutritional quality of barley.international journal of food and nutritional sciences, Vol.4, Iss.1, and JanMar.

William, P., H. Nakoul, K. Singh. (1983). Relationship between cooking time and some physical characteristics in chickpeas (Cicer arietinum L.) J. Sci Food Agric. 34: 492-496.

Yang, T., Duan, C.L., Zeng, Y.W., Du, J., Yang, S.M., Pu, X.Y., Yan,g S.C. (2013). HPLC analysis of flavonoids compounds of purple, normal barley grain. AMR;634:1486e90

Youssef, M.K.E. (2008). Nutritional assessment of telbina and telbina fortified biscuits. Home Econ. 18, 3-14

Youssef, M. K., El-Fishawy, F. A., Ramadan, S.A., Abd El-Rahman,A.M. (2013). Nutritional Assessment of Barley, Talbina and Their Germinated Products. Frontiers in Science, 3(2): 56-65.

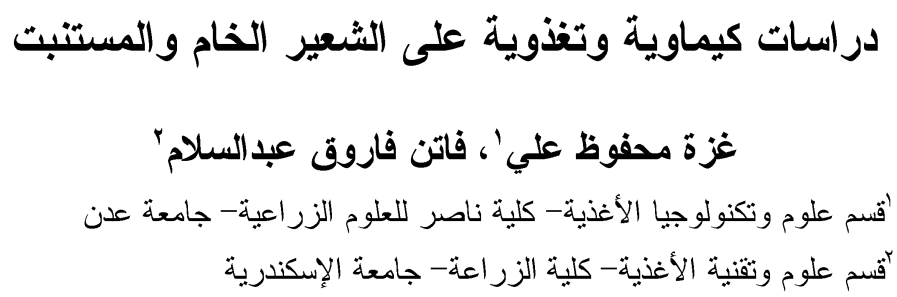

$$
\begin{aligned}
& \text { أظهرت هذه الدر اسة تأثير الإنبات على التركيب الفيزيائي و الكيميائي و المعادن ومحتوى الفيتامينات و الصفات }
\end{aligned}
$$

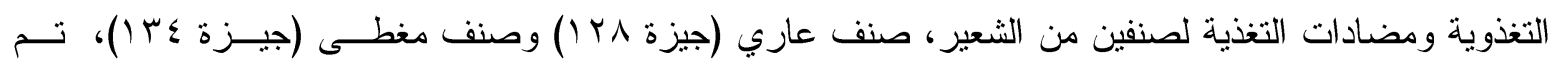

$$
\begin{aligned}
& \text { الحصول عليهما من مركز البحوث الزراعية - الجيزة- مصر . كما شملت الدراسة التقييم الحسي للتلبينة المحضرة } \\
& \text { من دقيق الثعير الخام و المستتبت (VY ساعة) لكل من الصنفين. }
\end{aligned}
$$

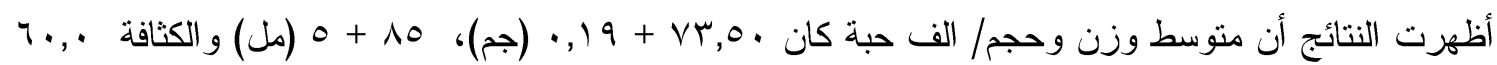

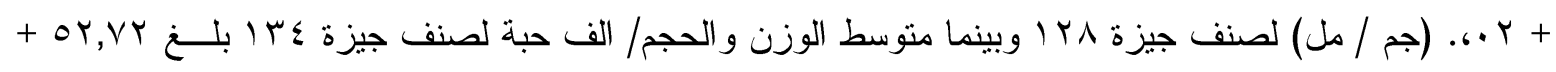

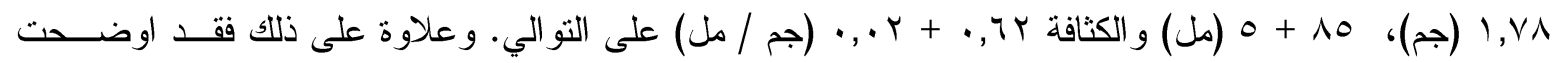

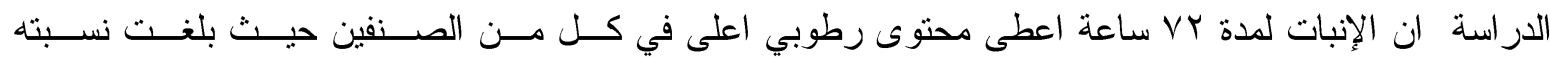




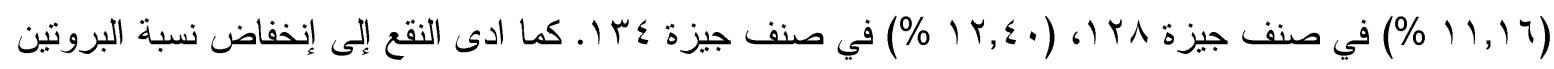

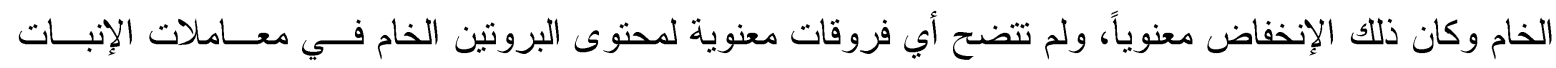

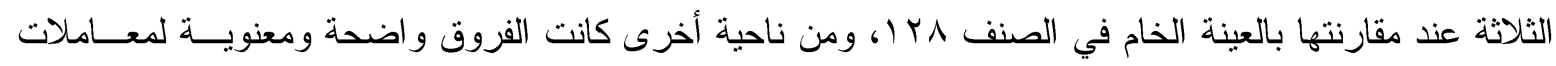

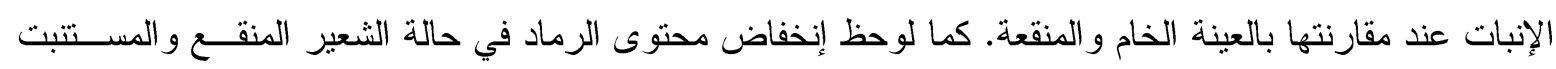

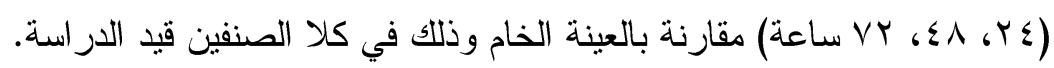

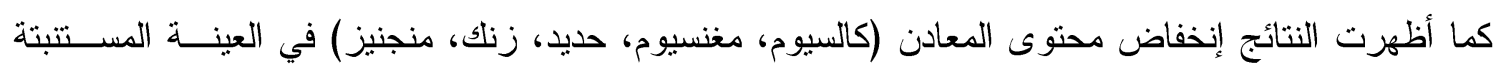

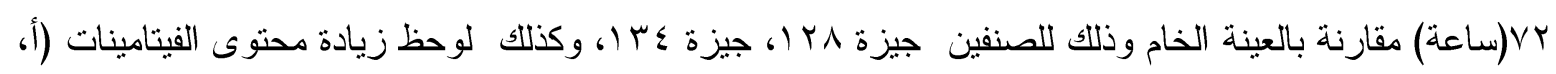

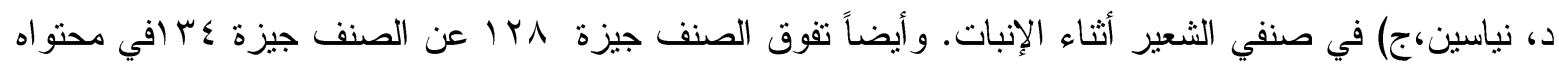

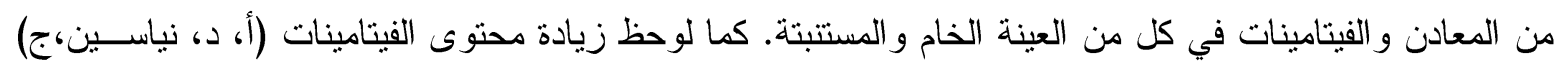

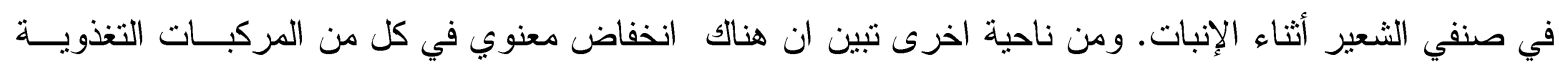

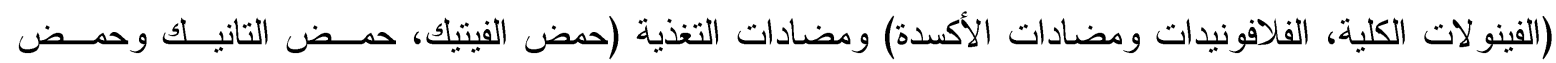

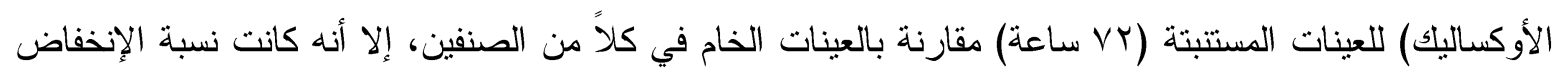

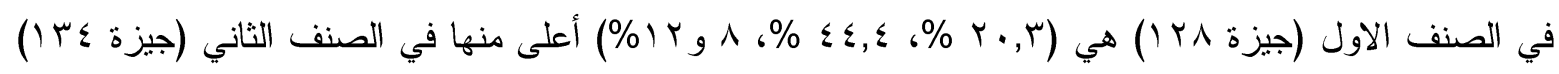

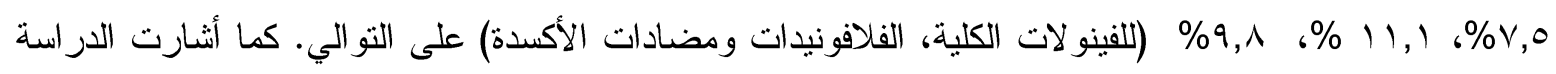

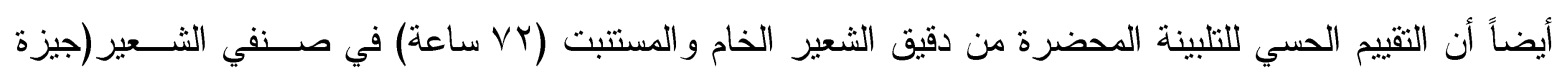

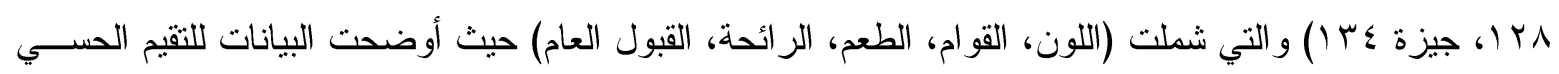
بوجود فروق معنوية بين كل من اللون و الطعم والقبول العام، في حين لايوجد فروق معنوية لصفات القو ام و الرائحة

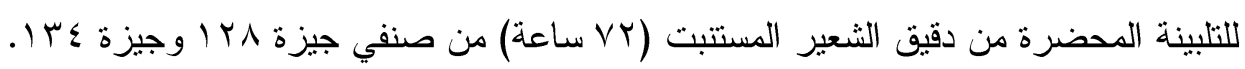

